\title{
Correction to: Effects of Agricultural Pollutants on Stress Hormones and Viral Infection in Larval Salamanders
}

\author{
Drew R. Davis ${ }^{1,2}$ (D) $\cdot$ Katie J. Ferguson ${ }^{1} \cdot$ Matthew S. Schwarz ${ }^{3} \cdot$ Jacob L. Kerby ${ }^{1}$ \\ Published online: 15 August 2020 \\ (C) Society of Wetland Scientists 2020
}

\section{Correction to: Wetlands}

https://doi.org/10.1007/s13157-019-01207-1

The original publication has been updated. A typographical error has been corrected and references have been updated.

Publisher's Note Springer Nature remains neutral with regard to jurisdictional claims in published maps and institutional affiliations.

The online version of the original article can be found at https://doi.org/ 10.1007/s13157-019-01207-1

Drew R. Davis

drew.davis@utrgv.edu

1 Department of Biology, University of South Dakota, 414 East Clark Street, Vermillion, SD 57069, USA

2 School of Earth, Environmental, and Marine Sciences, University of Texas Rio Grande Valley, 100 Marine Lab Drive, South Padre Island, TX 78597, USA

3 South Dakota Field Office, U.S. Fish and Wildlife Service, 420 South Garfield Avenue, \#400, Pierre, SD 57501, USA 